\title{
高齢者及び成人の歩行特性と歩行感からみた床仕上げ構造に関する検討 \\ WALKING IMPACT FORCE CHARACTERISTICS AND ELASTICITY OF FLOOR FINISHING MATERIALS FOR AGED AND ADULTS
}

\author{
富田隆太*, 井上勝夫**, 川又周太*** \\ Ryuta TOMITA, Katsuo INOUE and Syuta KAWAMATA
}

\begin{abstract}
In this research, we classified into groups the impact force characteristics of the walking habits of the elderly, and we got the physical factors that influence them. We also examined the comfortability for walking on various floor finishing materials when we classified them. As the result, we got the followings: (1) We could classify into 3 groups about the impact force characteristics by aged walking, (2) We could find out the heel angle of incidence as a walking factor, (3) There was several kind of floor impact force characteristics for normal walking of aged. The range of evaluation of rigidity of floors for the aged was narrower than for adults.
\end{abstract}

Keywords : Aged, Walking characteristics, Impact force characteristics, Action characteristics, Favor, Floor finishing materials

高齢者，歩行特性，衝撃力特性，動作特性，好ましさ，床仕上げ構造

1、はじめに

集合住宅を中心に、現在の木仕上げ構造は、その床衝撃音遮断 性能を重視するあまり、床本来の快適性、安全性を損なうょうな仕 様も出回っているのが現状である。床に求められる性能を考える と、他住戸への音響性能を考慮することは当然重要であるが、居住 者の快適性、安全性が損なわれることは、床本来の機能を逸してい ると思われ、今後の対策が必要と考えられる。特に、近年の高跲化 社会を鑑みると、高齢者にも配慮した上で、住空間の快適性の向 上、安全性の確保を、人間工学的な面も含め検討していく必要性が あると考えられる。我々は生活の場としての住宅床に求められる性 能として、音響性能はもちろんのこと、歩行時の感覚 (好ましさ、 安定性等)、さらには転倒時の安全性等を主な研究対象として、そ れらを総合的に検討し、生活の場としての適性な床仕上げ構造・仕 様を提案しようとしている。

本論文に関連する既往研究の状況をみると、住宅床のかたさ感 覚に関する研究として文献 1）～6）、高齢者歩行時の安全面からみ たすべりの評価に関する研究として文献 7）～9）などが挙げられる。

赤尾らは、住宅の床仕上げ材の歩行感について、床側と人体側 の両側面から種々の検討を重ねている。かたさに対応する床側の物 理量としては、静的・動的それぞれの物理量の検討を行い、特に文
献 2) では、足を含めた体各部の機械インピーダンスの測定を行い、 足のインピーダンスの低い落ち込みが $250 \mathrm{~Hz}$ 付近でみられ、かたさ

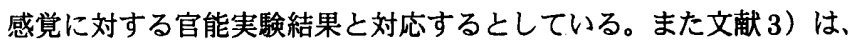
膝や腰などを含めた人体特性を調べるため、全身を載せることので きる加振装置を開発し、全身の機械インピーダンスの測定を行って いる。これらの研究成果は、人間の生活時 (歩行時)の感覚評価結果 を説明できる物理量となる可能性があり、今後の展開が期待され る。

また、小野、横山らは快適性ならびに疲労感の観点から、床の かたさに関する研究を行っている。文献 5 ) では、床のかたさ測定 装置の開発を行い、床衝撃時の床の変形特性から得られる物理量と かたさ感覚の評価尺度との対応性がよいとしている。また、文献 6) では高齢者を含め、安定性からみた床のかたさと凹凸に着目した 検討を行い、かたさと凹凸が複合された場合にも適用できる評価方 法を提示している。

さらに、小野、横山らは安全性からみた高莑者のすべりの評価 に関する研究を行っている。文献 7) では、過去の文献により高齿 者の歩行を整理し、高龄者装具の開発及びそれを装着した擬似高齢 者の妥当性の検証を身体機能と感覚の両面から行い、かつすべり評 価尺度と C.S.Rの関係に慗げている。文献 8)では、高齢者を対象と
* 日本大学理工学部建築学科 助手・工修

** 日本大学理工学部建築学科 教授. 工博

*** 日本大学大学院理工学研究科 大学院生
Assistant, Dept. of Architecture, College of Science and Technology, Nihon Univ., M. Eng.

Prof., Dept. of Architecture, College of Science and Technology, Nihon Univ., Dr. Eng.

Graduate Student, Graduate School of Science and Technology, Nihon Univ. 


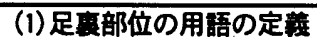

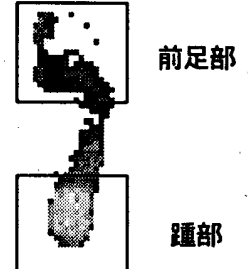

（2）街繁力波形の用語の定藉

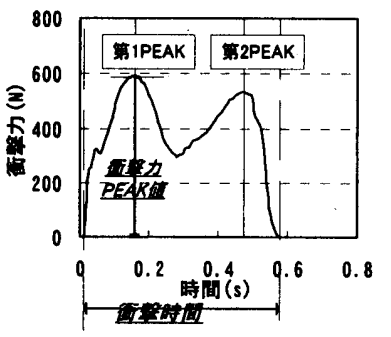

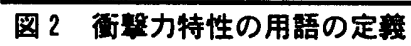

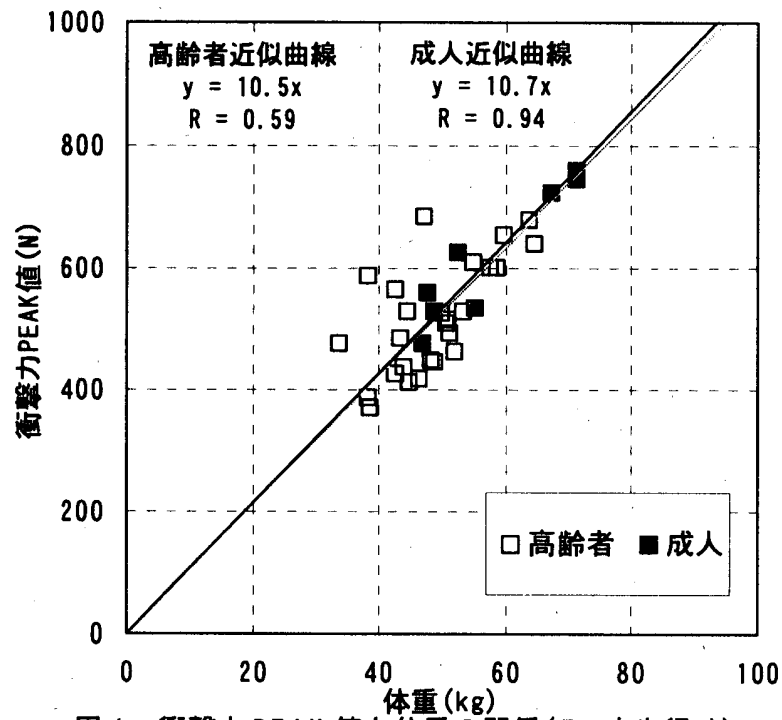

图 4 衡繁力 PEAK 值と体重の関係( FI 床步行時)

る。

高齢者の全体波形は、いわゆるすり足歩行のため、明確な PEAK を持たない台形形状を示している。また、成人に比べて高齢者の波 形には個人差が大きい。特に、踵部と前足部の衝撃力時間的特性に 差があり、被験者 NO.2、9 のような踵部が衝撃力波形の後方にまで 影響しているものや、NO.24のような前足部が衝撃力波形の初期か ら影響しているもの等、人によって大きな差がある。このような前 足部や踵部の時間的・空間的特性の差は、床の変化に対する歩行時 の感覚に大きく影響を与えることが予想される。

図 4 に高齢者と成人の全被験者の衝撃力 PEAK 值と体重との関 係を示す。これをみると、全体的な衝撃力ピーク值の分布は、体重 の約 1.1 倍程度を示しているが、相関係数をみると成人の 0.94 に比 ベ、高齢者は 0.59 とかなり低い。また、四 5 に足裏各部位の衝撃力 PEAK 比率を示す。衝撃力 PEAK 比率は、衝撃力をそれぞれ被験者 の体重で除した值とした。これをみると、図 4 に示したように、全

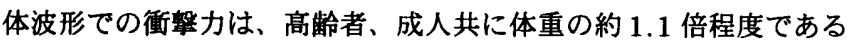
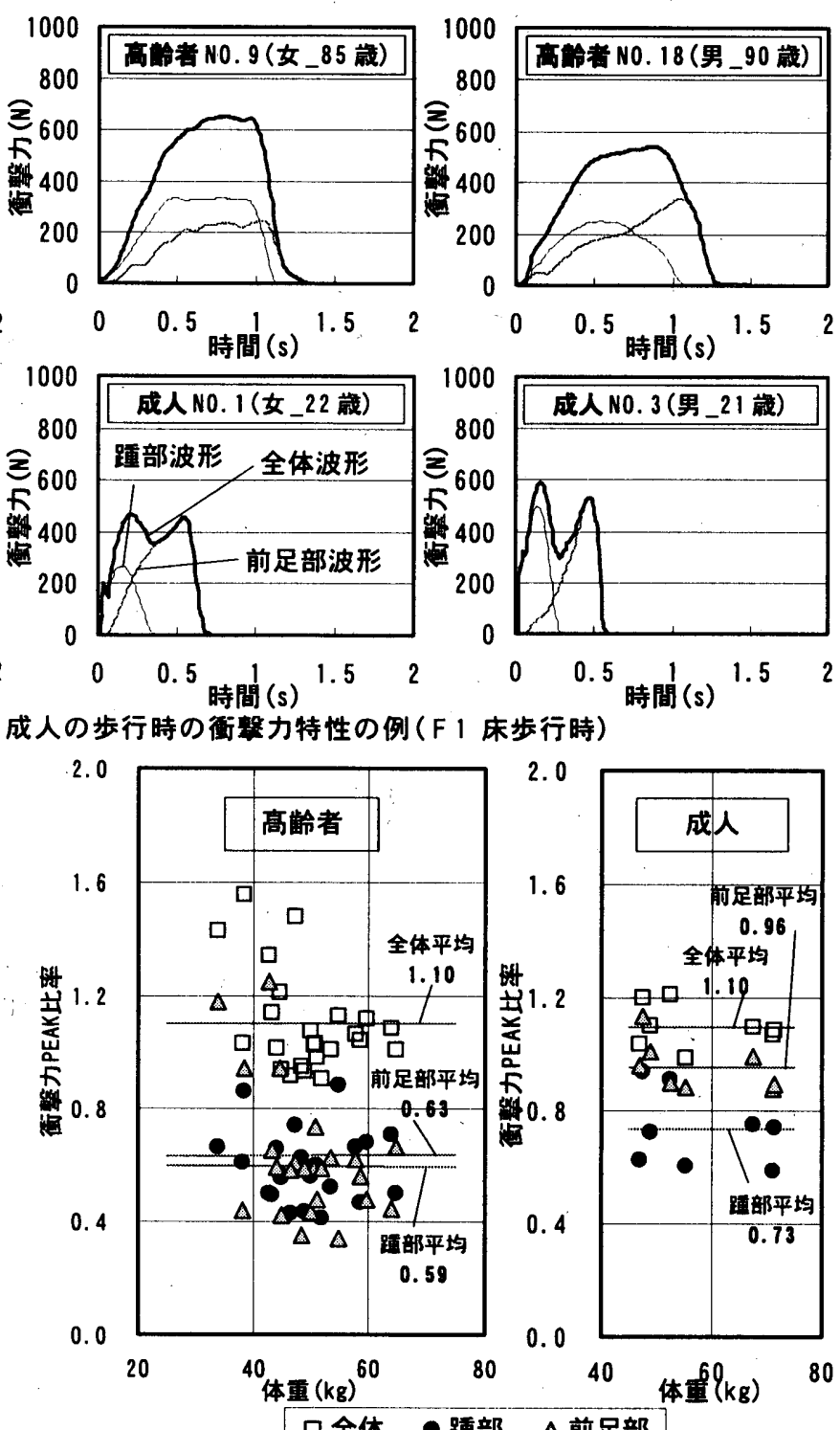

口全体 - 踵部 $\Delta$ 前足部

図 5 足裏各部位の衙撃力 PEAK 比率(F1 床步行時)

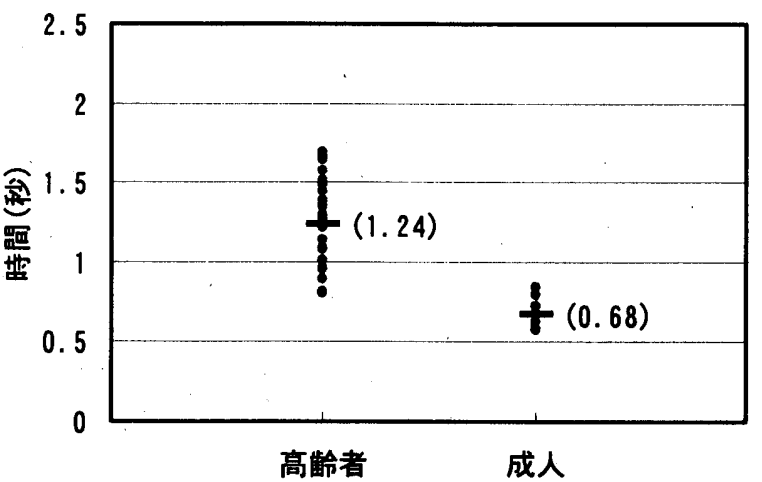

図 6 衝䡶時間のばらつき（F1 床步行時）

表 3 両足の衙撃時間の比較（F1 床步行時）単位:sec

\begin{tabular}{|c|c|c|c|c|c|c|}
\hline \multirow{2}{*}{} & \multicolumn{3}{|c|}{ 高罡者 } & \multicolumn{3}{|c|}{ 成人 } \\
\cline { 2 - 7 } & 左足 & 右足 & 平均 & 左足 & 右足 & 両足 \\
\hline 平均 & 1.23 & 1.25 & 1.24 & 0.69 & 0.66 & 0.68 \\
\hline 最大値 & 1.66 & 1.83 & 1.69 & 0.86 & 0.81 & 0.84 \\
\hline 最小値 & 0.78 & 0.79 & 0.80 & 0.59 & 0.55 & 0.58 \\
\hline 僄準偏差 & 0.27 & 0.28 & 0.27 & 0.09 & 0.09 & 0.09 \\
\hline
\end{tabular}


が、踵部、前足部の比率では高齢者と成人で大きく異なる。特に、 成人の場合、踵部の 0.73 に比べ、前足部では 0.96 倍と大きく、足 裹離脱時の指部による”蹴り”の動作が大きく影響している。一 方、高齢者は踵部、前足部とも、体重の 0.6 倍程度になっており、成 人のようなスムーズな步行を行っていないことがわかる。これら は、高齢者の歩行が不安定であり、特に膝下の動きが不十分なこと を示すもので、さらにデータのばらつきから歩行方法に個人差が大 きいことを裏付けるものである。

全被験者の衝撃時間（足裹の床への接触時間）のばらつきを図 6 に、左右の足の衝撃時間の平均、最大、最小值を高齢者と成人を比 較して表 3 に示す。図 6 に示すように、高齢者は成人に比べ、平均 值で 2 倍程度の時間を示している。また、高齢者の衝撃時間のばら つきは大きく、同じ高齢者の中でも 2 倍以上の変化があることがわ かる。同様に、表 3 に示すように、左足、右足とも、成人に比べて 高㱓者は、かなり大きいばらつきを示しているが、高齢者も成人も 左右の足による衝撃時間の差は被験者間では非常に小さい。 3-2. 動作特性

高齢者と成人の歩行時の動きを捉えるため、図 1 に示した体各部 のマーカーの動きについて分析を行った。その軌跡の例を図 7 に示 す。これをみると、高龄者、成人共に頭部から腰部における鈶直方 向の動きは小さいが、肩から腰のラインの角度で判るように高㱓者 はほほ垂直な姿勢で歩行している。また、頭部と肩部を結ぶ角度の
変化は非常に小さい。このように、歩行時における上半身の上下方 向の動きは非常に少ないと考えられたので、傣から下を対象に詳細 な検討を行った。ここで、足裏が休面に接触している(すなわち床 を加振している）時間に上半身の軌跡に変化が少ないことから、床 に及ぼす衝撃力に対して、上半身は質量のみが静的に作用すると考 えることができる。図 8 に、踵入射時から同じ足の次の踵入射時ま での 1 周期における、瞅下の足各部の軌跡例を実寸で示す。図中に は足の動きを把握するために特に重要と考えられる銷直変位や角度 の定義を示す。ここでいう膝、踵、指部の鈶直方向変位は、歩行周 期の中での鈶直方向の変位の最大值と最小值の差であるが、個人の 足の長さに依存しない結果を得るため、図 9 以降では、大腿部から 床までの長さに対する比率として表わした。また、踵入射角、指部 離脱角は水平面に対して図中に示すような角度とした。ストライド 長、歩行周期は、歩行の 1 周期における距離と時間をいう。ストラ イド長も個人の足の長さに依存しない結果を得るため、図 9 以降で は、ストライド長比率として、大腿部から床の長さに対する比率で 表わした。

図 9 に高路者と成人の足各部位の鈶直変位率、角度、ストライ ド長比率、歩行周期の結果を示す。また表 4 に高㱓者と成人の 1 元 配置の分散分析結果、表 5 に各因子の相関係数を示す。

図 9 をみると、膝部以外の足各部の動作で、成人は高龄者に比べ よく足をあげ、脚力のある歩行をしていることがわかる。また、ス
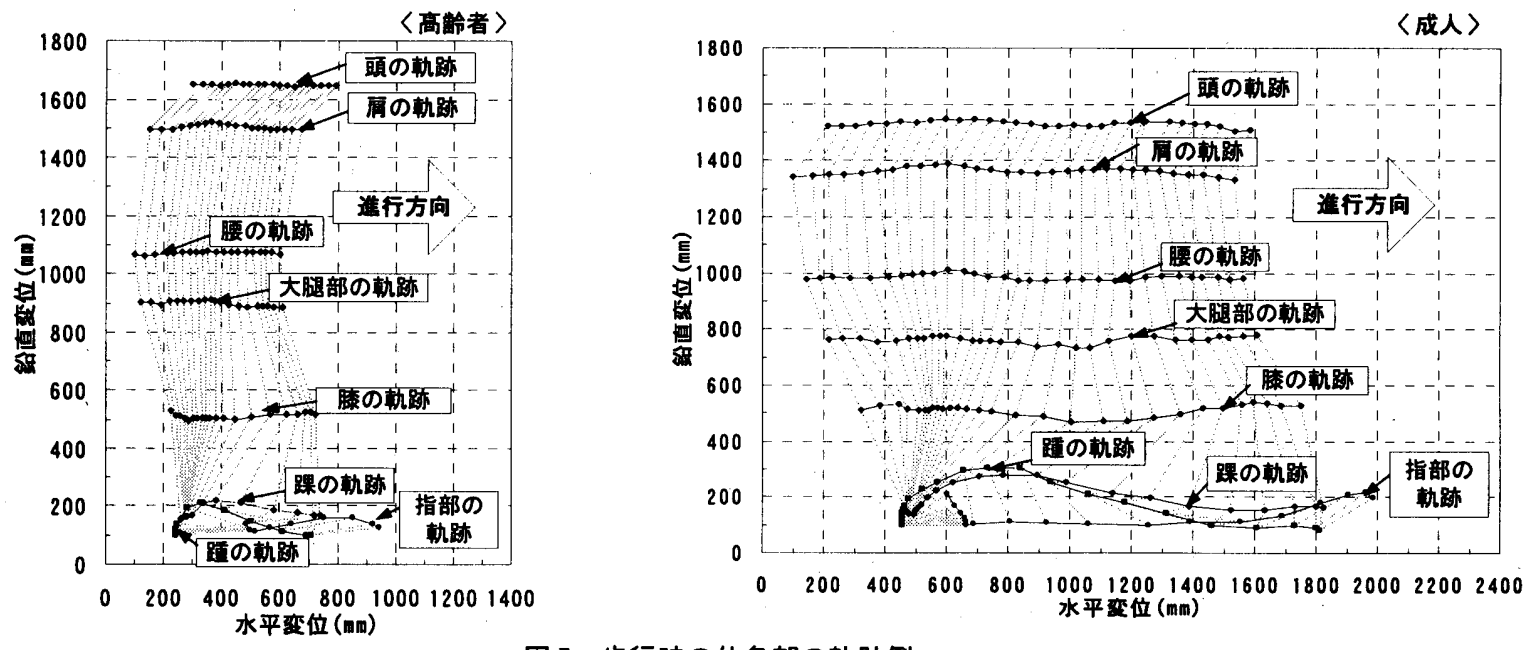

図 7 歩行時の体各部の軌跡例

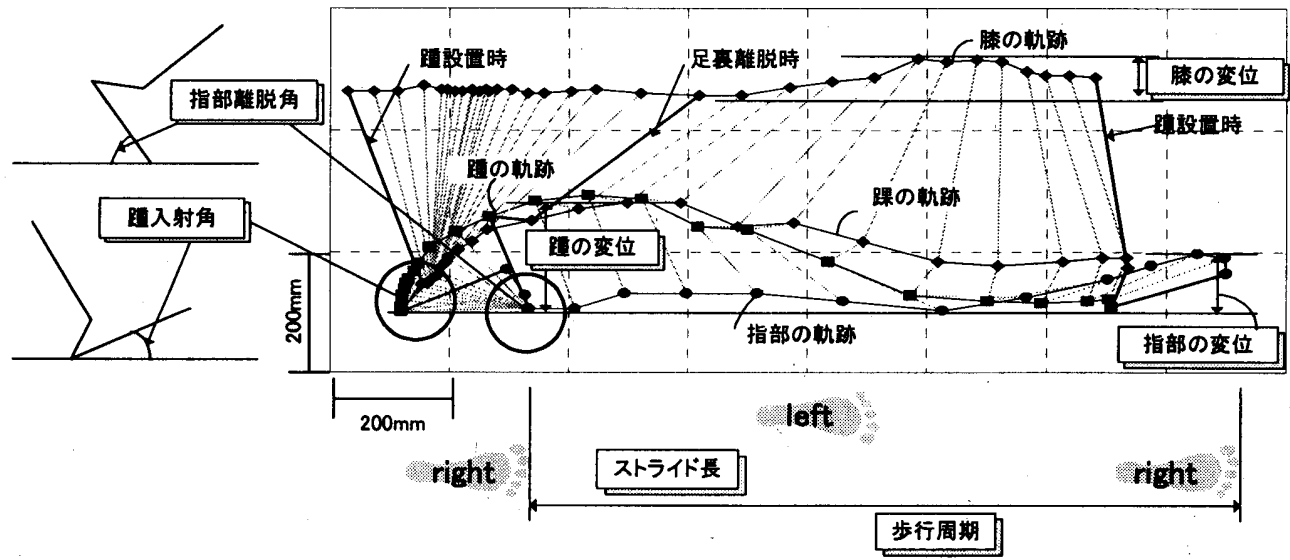

図 8 足各部の軌跡と本研究での用語の定韸 

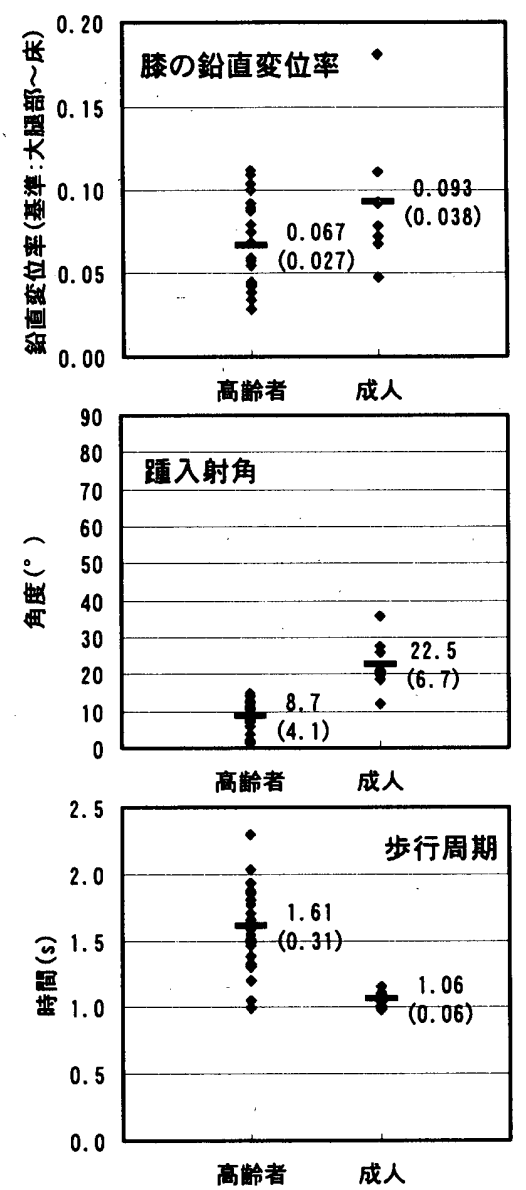

表 4 分散分析結果

\begin{tabular}{|c|c|}
\hline & 耛果 \\
\hline 睞の鈶直变位比率 & * \\
\hline 踵の鈶直变位比率 & $* * *$ \\
\hline 指部の铅直变位比率 & $* * *$ \\
\hline 踵入射角 & $* * *$ \\
\hline 指部離脱角 & $* * *$ \\
\hline ストライド長比率 & $* * *$ \\
\hline 歩行周期 & $* * *$ \\
\hline 歩行速度 & $* * *$ \\
\hline
\end{tabular}

$* * *: 1$ 亿゙有意
$*: 5 \%$ 有意
注 : 比率の基準は
大腿部〜床面

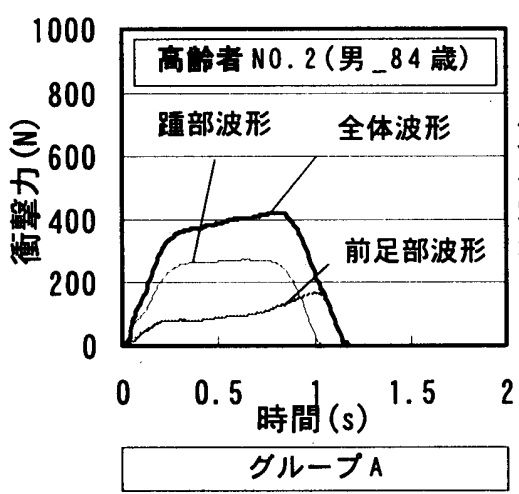

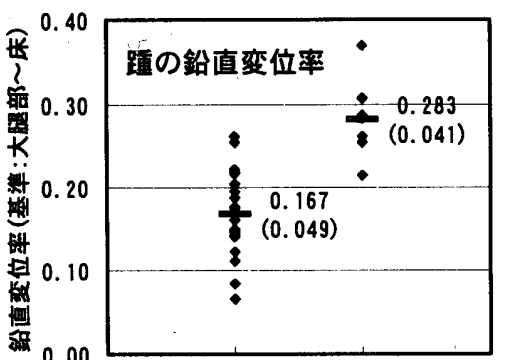
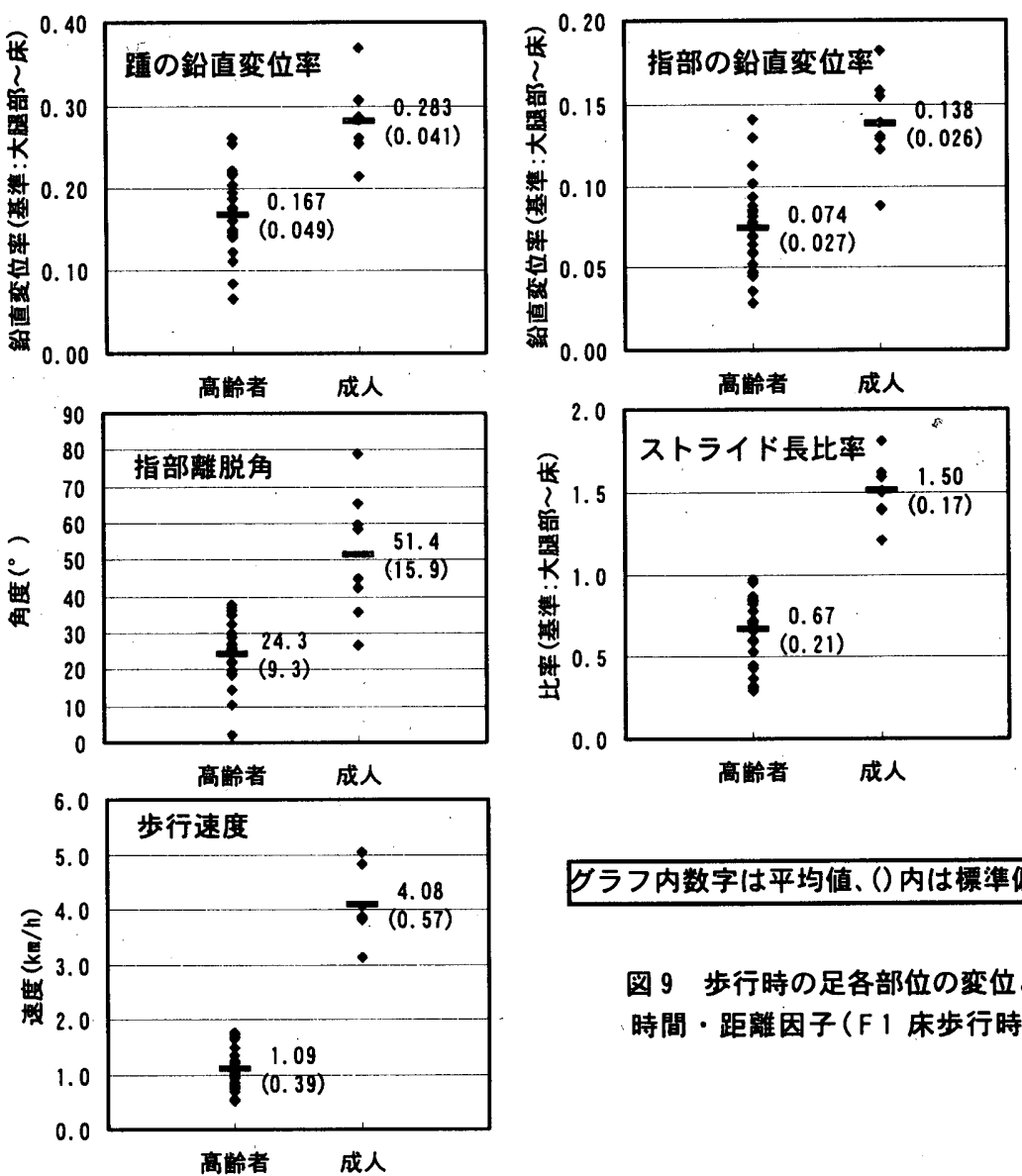

タラフ内数字は平均值、()内は標準偏差

図 9 歩行時の足各部位の变位と 時間・距離因子（F1 床步行時）
表 5 相関係数

\begin{tabular}{|c|c|c|c|c|c|c|c|c|c|}
\hline \multicolumn{2}{|c|}{} & $\langle 1\rangle$ & $\langle 2\rangle$ & $\langle 3\rangle$ & $\langle 4\rangle$ & $\langle 5\rangle$ & $\langle 6\rangle$ & $\langle 7\rangle$ & $\langle 8\rangle$ \\
\hline$\langle 1\rangle$ & 瞅の鉛直変位率 & & & & & & & & \\
\hline$\langle 2\rangle$ & 踵の鉛直变位率 & 0.53 & & & & & & & \\
\hline$\langle 3\rangle$ & 指部の鉛直变位率 & 0.55 & 0.64 & & & & & & \\
\hline$\langle 4\rangle$ & 踵入射角 & 0.25 & 0.60 & 0.59 & & & & & \\
\hline$\langle 5\rangle$ & 指部離脱角 & 0.20 & 0.76 & 0.45 & 0.72 & & & & \\
\hline$\langle 6\rangle$ & ストライド長比率 & 0.35 & 0.88 & 0.69 & 0.70 & 0.76 & & & \\
\hline$\langle 7\rangle$ & 步行周期 & -0.16 & -0.45 & -0.62 & -0.49 & -0.40 & -0.52 & & \\
\hline$\langle 8\rangle$ & 步行速度 & 0.30 & 0.83 & 0.72 & 0.76 & 0.79 & 0.95 & -0.70 & \\
\hline
\end{tabular}

は、相闋係数0.8以上 注 : 比率の基準は は、相関係数 0.7 以上 大腿部〜床面
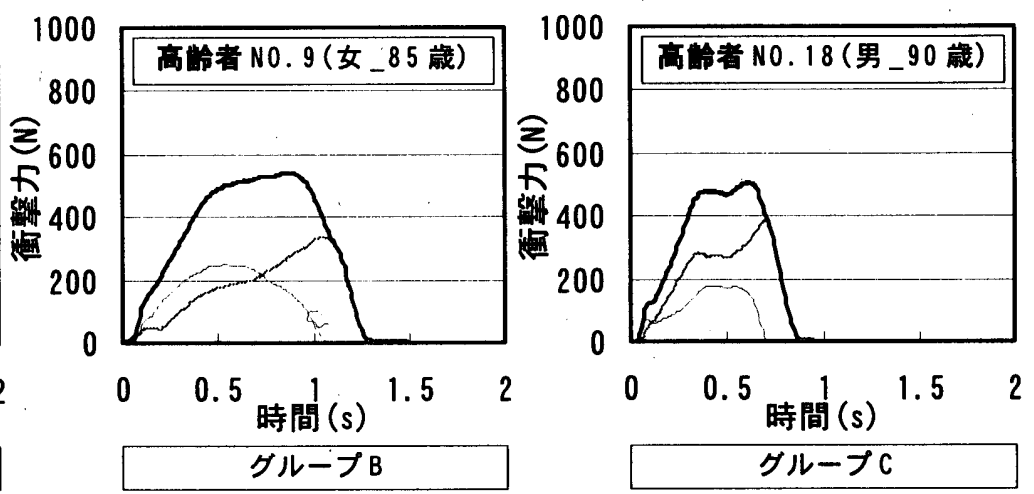

图 10 高跉者步行時のグルーブ分類例 
トライド長比率をみても、成人は高齢者に比べ、明らかに 大きく、大股で歩行をしている。高齢者の歩行状態は、足 の鈶值方向変位の上下動が小さく、すり足歩行であること がこの結果からも裏付けられ、住宅内での段差が数 $\mathrm{m} \mathrm{m}$ あっても、つまづき等の危険性があると言える。

表 4 に示すように、眿部の鈶直方向変位率以外は、高齢 者と成人の差は $1 \%$ 末満で有意であり、明確な差があること を示している。また、表 5 に示すような歩行動作を表わす 各因子間の相関は、比較的高い数值を示している。しかし、 膝の鈶直変位率と他の因子との相関は弱く、㮩部が歩行に与える影 響は、他の因子に比べて小さく、主に膝から下の足各部の動作、特 に踵の鈶直方向变位率、踵入射角、指部離脱角、歩行速度などの特 性を把握することが重要であると考えられる。

4、高齢者床歩行時の足裹接触部位の時間变化からみたグループ分 類とそれに影響を与える歩行動作要因の抽出 4-1. グループ分類

高齢者の衝撃力特性の結果 (3-1) をみると、足裏各部位の時間的 特性は、個人差が大きく、ひとつのグループとして捉える ことは難しい。また、歩行時の感覚を考える上で、足裏各 部位の時間的、空間的変化は大きく影響することが予想さ れる。そこで、床への衝撃入力時の各部位の波形と時間的 変化からみた高齢者のグループ分類を行った。

分類の例を図 10 に示す。A グループは、踵部の波形が主 に全体波形の形状に影響し、衝撃時間の終わりの方に踵部 と前足部が交差しているものとした。すなわち、この步き 方は踵部に依存した歩き方と言える。B グループは、踵部 と前足部の両方が全体波形の形状に影響し、両者がほぼ衝 撃時間の中央で交差しているものとした。すなわち、足裏 全面で床に接触しているすり足歩行ではあるが、踵部から前足部へ の重心移行が確実に行われている、高齢者の中では成人に近い歩行 と言える。C グループは、前足部の波形が主に全体波形の形状に影 響し、衝撃時間の始めの方に踵部と前足部が交差しているものとし た。すなわち、この歩き方は前足部に依存した歩き方と言える。以 上のような 3 パターンに分類し、さらに検討を行った。

表 6 にグループ分類後の該当人数と被験者の諸元を示す。これ をみると、A、B グループの対象人数が約半数ずつを占めている。C グループは、対象者が 2 人之少なく、感覚評価実験、歩行特性等で 適正な検討を行うことは難しいと判断されるため、本研究では、主 にA、B のグループについて検討を行うことにした。図 11 に示すよ うに、グループ別の年踰構成をみると、グループ A、B 共に平均も ばらつきもほぼ同様の傾向があることから、年齢による足裏各部位 の衝撃力特性への影響は小さいことがわかる。

4-2. 歩行グループ分類に影響を与える動作特性の抽出

高踰者の床面への足裏接触部位の時間変化からみたグループ分 類を行ったが、前述したようにグループごとの変化に年齢の影響は 少ないものと考え、3-2.(図9) で示した歩行因子を対象として検討を 行った。歩行グループ別の各因子の平均值と標準偏差、及び分散分
表 6 高齢者グループ分類後の被験者の諸元

〈內は、平均値

\begin{tabular}{|c|c|c|c|}
\hline 被験者の属性 & 高齢者Aタルルーブ & 高秢者Bグループ & 高齢者Cグループ \\
\hline 被䀫者数（人） & 11 & 11 & 2 \\
\hline 男性人数 (人) & 6 & 2 & 0 \\
\hline 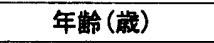 & $65 \sim 92\langle 80\rangle$ & $67 \sim 90\langle 82\rangle$ & $86 \sim 87\langle 87\rangle$ \\
\hline 体重 $(\mathrm{kg})$ & $38.3 \sim 63.8\langle 50.5\rangle$ & $33.8 \sim 64.6\langle 49.6\rangle$ & $42.8 \sim 44.6\langle 43.7\rangle$ \\
\hline 足の大きさ $(\mathrm{cm})$ & $20.8 \sim 24.3\langle 22.9\rangle$ & $21.0 \sim 24.8\langle 22.4\rangle$ & $21.3 \sim 21.3\langle 21.3\rangle$ \\
\hline 大腿部～床面 $(\mathrm{cm})$ & $61.5 \sim 77.5\langle 71.5\rangle$ & $61.5 \sim 84.0\langle 72.3\rangle$ & $61.5 \sim 66.5\langle 64.0\rangle$ \\
\hline 睖部〜床 $(\mathrm{cm})$ & $37.0 \sim 44.5\langle 39.7\rangle$ & $33.5 \sim 47.0\langle 40.9\rangle$ & $36.5 \sim 37.0\langle 37.0\rangle$ \\
\hline 蹧部〜床 $(\mathrm{cm})$ & $2.0 \sim 8.0\langle 6.0\rangle$ & $4.8 \sim 7.5\langle 5.8\rangle$ & $5.5 \sim 6.0\langle 5.8\rangle$ \\
\hline
\end{tabular}

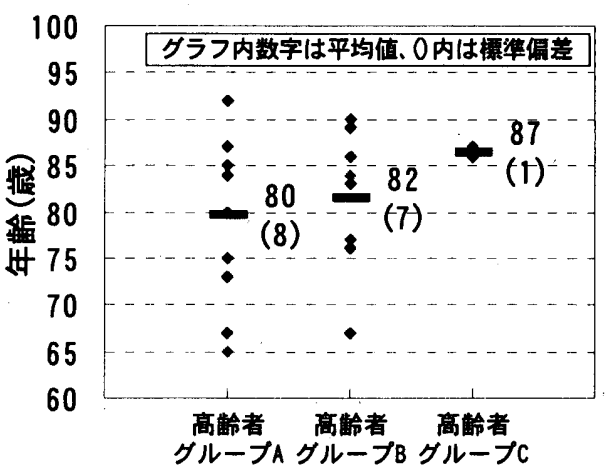

图 11 グルーブ分類後の年齢の分布

表 7 ダルーブ分類後の歩行因子と分散分析結果

\begin{tabular}{|c|c|c|c|c|c|}
\hline & \multicolumn{2}{|c|}{ 高跉者グルーブ } & \multicolumn{2}{|c|}{ 高酫者グルーブ } & 分散分析 \\
\hline & 平均值 & 㯨準偏差 & 平均値 & 標準偏差 & 結果 \\
\hline 䐂の鉛直変位率 & 0.057 & 0.019 & 0.075 & 0.029 & - \\
\hline 踵の鉛直変位率 & 0.145 & 0.041 & 0.181 & 0.051 & - \\
\hline 指部の鉛直変位率 & 0.074 & 0.033 & 0.073 & 0.023 & 一 \\
\hline 酒入时角( & 6.0 & 4.0 & 11.6 & 2.0 & $* * *$ \\
\hline 指部離脱角 $\left(^{\circ}\right)$ & 21.9 & 10.0 & 26.9 & 8.6 & 一 \\
\hline ストライト長比率 & 0.59 & 0.19 & 0.70 & 0.21 & - \\
\hline 歩行周期 (s) & 1.60 & 0.28 & 1.61 & 0.33 & - \\
\hline 歩行速度 $(\mathrm{km} / \mathrm{h})$ & 0.98 & 0.36 & 1.16 & 0.39 & - \\
\hline
\end{tabular}
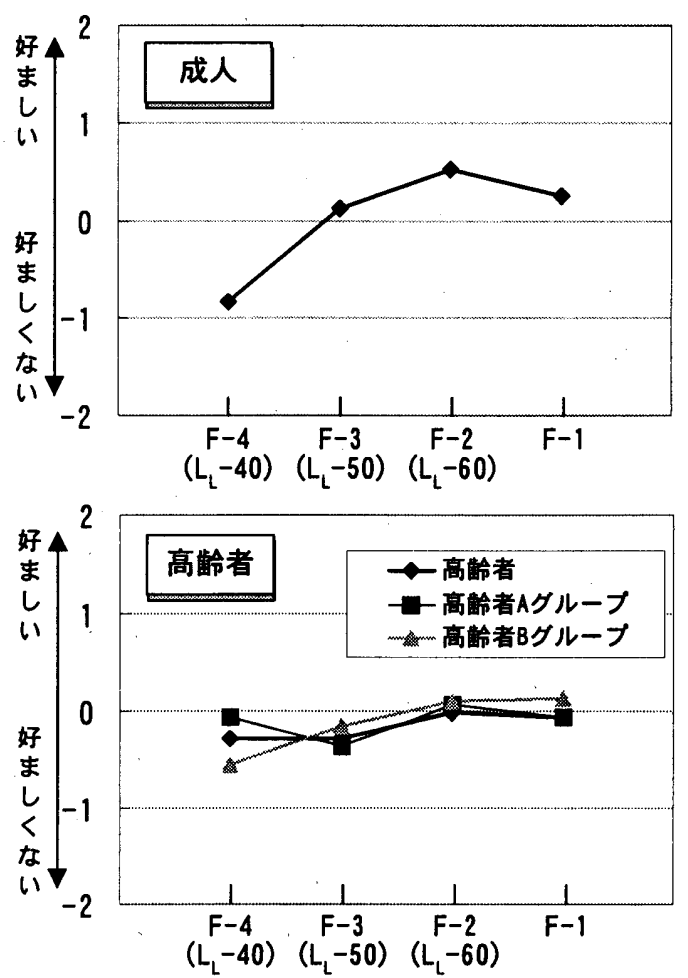

图 12 フローリング床歩行時の好ましさの評価 
析結果を表 7 に示す。これをみると全体的な傾向としては、成人に 近い歩行であるグループ B の方が值が大きく、運動機能の低下は 比較的小さいことがわかる。特に、踵入射角は、高齢者のグループ $\mathrm{A}$ に対して B は約 2 倍程度大きく、1\% 未満の有意差もみられたこと から、足裏各部位の衝撃力特性に大きく影響を与える歩行動作要因 であると言える。

\section{5、歩行感覚評価実験}

高齢者と成人に表 1 に示した各床仕上げ構造の上を歩いてもら い、歩行時の好ましさについて 5 段階尺度による評価をヒアリング 方式で行った。さらに、高齢者と成人の評価結果を系列範疇法で尺 度化した。本研究では、まず体種別について検討を行ったが、高龄 者にとって最も好ましいとされる床は畳床 (T 1) であった。成人で は、好ましい床として直張り木質フローリング床が選択され、その 中ではF-2 床を最も好ましいとし、F-4 床を最も好ましくないとし た。F-2 と F-4 は同じ表面仕上げ材であるが、床の硬さ (弾性) の異な る床仕上げ構造である。高齢者の畳床への評価が高いのは、被験者 がかつて経験し、制染みがあり安心できる床であるためと考えられ ることから、この評価は脚部に対する適性弾性による判断というよ りも馿染みや安心感による反応と考えられる。よって、特に年齢の 增加に伴い影響が強くなるものと予想される。これらの結果から、 畳床は別の判断基準から高跉者にとって好ましい一つの床仕上げ構 造と位置づけられる。しかし、住宅床を想定すると、各部屋ごとに 用途が異なることや生活している床は時代によって変化することが 予想されること等を考えると、適性な床種別の提案はもちろんのこ と、同種別の床材の中でも適性な弾性を有する床を提案していく必 要性があると考えられる。

そこで、本研究では、特に直張り木質フローリング床の硬さを 変化させた場合の高齢者と成人の歩行時の好ましさについて検討し た。その結果を図 12 に示す。また、既報の成人を対象とした結果 ${ }^{11)}$ を図 13 に示す。さらに、今回対象とした試験床の衝撃インピー ダンス值を表 8 に示す。図 12 をみると、成人は、前述のように F2(LL-60) のフローリング床に対して、最も好ましい評価値を示して いる。F-2 の衝撃インピーダンス值は、表 8 で示すように約 $80 \mathrm{~dB}$ で あり、図 13 に示した既報の結果 ${ }^{11)}$ と良く対応している。図 12 から 高跉者全体でみると、成人に比べて、各フローリング床の好ましさ に対する評価の幅が小さく、成人が好ましくないとしている F-4(LL 40）に対する評価も落ちていない。この結果から、高龄者全体を考 えると、特に遮音性能の高いフローリング床を使用しても、成人に 比べて歩行感としては顕著な問題は発生しないと言えそうである。 しかし、グループことにみると、成人に近い歩行であるグループ B は、成人に比べて、各床での絶対的な評価の差は小さいが、近似し た傾向を示し、硬いフローリング床を好ましいと感じていることが わかる。これは、足裏接触部位の時間的変化による床面の感覚にお いて、B グループの方が成人に近い歩行を行っているためであると 推察され、高齢者間で違いがあると予想される。

以上の結果から、高齢者に歩行感の面で適した床仕上げ構造を 提案して行く上では、足裹の時間的な変化を考慮した上でグループ

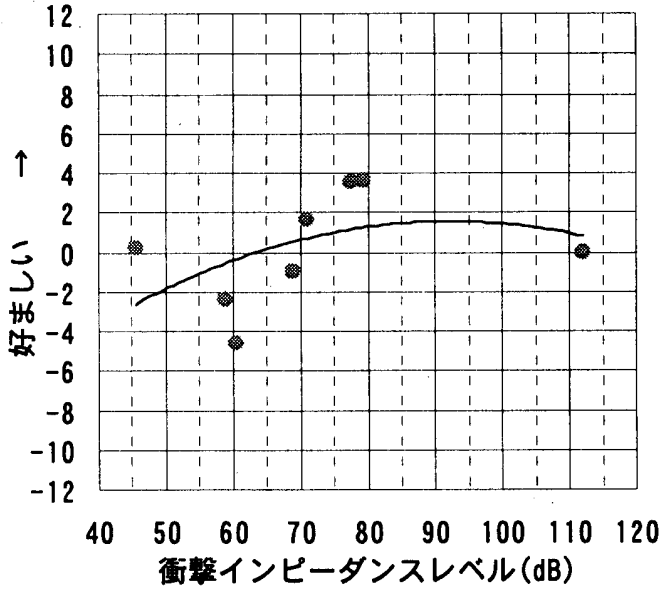

図13 好ましさと衙繋インピーダンスの関係 111

表 8 試倹床の衡撃インピーダンス

\begin{tabular}{|c|c|c|}
\hline 試倹床 & 公称遮音等极 & 衛整インピータンスレベル \\
\hline$F-4$ & $L_{L}-40$ & $60.7 \mathrm{~dB}$ \\
\hline$F-3$ & $\mathrm{~L}_{\mathrm{L}}-50$ & $63.7 \mathrm{~dB}$ \\
\hline$F-2$ & $L_{L}-60$ & $80.4 \mathrm{~dB}$ \\
\hline$F-1$ & & $81.3 \mathrm{~dB}$ \\
\hline
\end{tabular}

別に検討して行く必要性が示唆されたと言える。

6、まとめ

高齢者と成人を対象に、平坦床歩行時の衝撃力特性、動作特性の 計測及び分析を行うと共に、床歩行時の感覚評価を行った結果、次 のような研究成果を得た。

（1）高齢者の衝擊力 PEAK 值は、被験者全体でみると成人とほぼ 同様の体重の約 1.1 倍を示すが、個人差は非常に大きい。

（2）成人の前足部波形の衝撃力 PEAK 值は、踵部に比べて全体的 に大きく、体重分程度に分布しているが、高齢者は踵部、前 足部共に平均值でみると、体重の約 0.6 倍を示し、ばらつきが あり一様な特性は見出せない。

（3）歩行時における頭から腰にいたる体各部の鈶直方向の軌跡を みると、歩行周期の中では変化は小さく、水平性が保たれて おり、足襄の圧力に及ぼす動的影響は小さい。

（4）高齢者と成人の足各部の動作では、暞下部分が大きく異なる。

（5）高齢者の衝撃力特性を足裹の変化として分類することができ た。また、この分類は年齢との相関がみられず、身体特性に 影響があると推察される。

（6）高齢者のグループ分類に影響を与える動作特性として、踵入 射角は有意差が認められ、歩行時における衝撃力特性を決定 する重要な要因であることを示した。

（7）直張り木質フローリング床を対象としたときの歩行時の好ま しさは、成人では従来の傾向どおり、適性な硬さ範囲がある ことを確認したが、高歯者の場合、総合的にみると、どのフ ローリング床でもほとんど変化がなく、遮音性能の高いフ 
ローリング床を用いても顕著な問題は発生しない。しかし、成 人に近い歩行特性を示すグループの場合、好ましさの変化の 幅は、成人に比べて狭くなるが、フローリング材の好ましさ では近似した傾向を示す。

以上のように、本研究では、高齢者の平坦路の步行時における 足裹各部位の衝擊力特性の時間的変化によりグループ分類を行っ た。これにより、フローリング床材における感覚評価も異なってく ることが示唆され、かつ歩行時の重要なパラメーターとして踵入射 角が挙げられることを示した。また、歩行時の衝撃力特性は加齢に よるものではないことが示され、身体特性等による分類が必要であ ることが分った。今後は、更に身体特性を表わす物理要因の抽出や 物理量の把握を行い、感覚評価との関係性を明らかにし、また音響 性能等も加味した上で床断面仕様の検討を行っていく予定である。

\section{【参考文献】}

1) 赤尾伸一、阿部政紀、岩本毅他：住宅の休仕上げ材の遮音性能と歩行感 に関する研究(その 8 静的及び動的試験から得られる物理量と官能との対 応)、日本建築学会大会講演梗概集、D-1 分冊, pp. $97 \sim 98,1996.9$ 2) 赤尾伸一、岩本媇、藤井弘義他 : 住宅の休仕上げ材の遮音性能と歩行感 に関する研究(その 10 足の機械インピーダンスの測定)、日本建築学会大 会講演梗概集、D-1 分冊, pp. 177 178, 1997.9

3）赤尾伸一、岩本競、鴄田泰他 : 住宅の床仕上げ材の遮音性能と歩行感に
関する研究(その 17 全身の機械インピーダンスレベルの測定)、日本建築 学会大会講演梗概集、D-1 分冊, pp. $275 \sim 276,2000.9$

4）小野英哲、横山裕、大野隆造：居住性からみた木㦿のかたさの評価方法に 関する研究 その 1 休のかたさに関する心理学的尺度の構成、日本建築学 会構造系論文集、第 358 号, pp. $1 \sim 8,1985.12$

5) 小野英哲、横山浴 : 居住性からみた朱のかたさの評価方法に関する研究 （その 2） 床のかたさ测定装置の設計・試作および床のかたさの評価指標， 評価方法の提示、日本建築学会構造系論文集、第 373 号, pp. $1 \sim 8,1987.3$ 6) 小野英哲、高橋宏樹 : 足元の安定性からみた床および路面のかたさと凹 凸の相対的評価方法の揭示、日本建築学会構造系論文集、第 496 号, pp. 23 $\sim 28,1997.6$

7) 横山裕、小野英哲、稲垣太郎他：高齢化にともなう歩行メカニズムの変 化からみたすべりの評価の相対的変化の推定、日本建築学会構造系論文集、 第 478 号, 1995. 12, pp. $35 \sim 44$

8）小野英哲、高橋宏樹、泉諆太他 : 高齢者の安全性からみた床および斜路 のすべりの評㑛方法、日本建築学会構造系論文集、第 484 号, p p. $21 \sim$ $29,1996.6$

9)佐々木植人，有川智，三橋博三，野村希晶，小野英哲，三上貴正：木仕上 材料のすべりやすさと歩行特性の関係に関する基磷的研究、日本建築学会 構造系論文集、第 501 号, pp. $19 \sim 24,1997.11$

10）井上勝夫、木村 翔、畕田隆太：平坦床，階段，スロープの歩行時にお ける高龄者の䘖撃力特性、日本建築学会計画系論文集、第 541 号, pp. 1 〜 $8,2001.3$

11) 井上勝夫、木村 翔、平光厚雄、矢後佐和子、渡辺秀夫：歩行感から見 た住宅㦿の感営評価に関する研究（歩行感からみた住宅床の振動応答特性 と本衝撃音遮断性能に関する研究：その3)、日本建築学会計画系論文集、 第 504 号, pp. $9 \sim 16,1998.2$ 